\title{
Comparative Base Sequence Homologies of the Deoxyribonucleic Acids of Erwinia Species and Other Enterobacteriaceae
}

\author{
J. M. GARDNER and C. I. KADO \\ Department of Plant Pathology, University of California, \\ Davis, California 95616
}

\begin{abstract}
Twenty-six strains representing ten species of Erwinia were examined by deoxyribonucleic acid (DNA)-DNA hybridization techniques for relatedness to each other as well as to other members of the family Enterobacteriaceae, including the genera Escherichia, Salmonella, Klebsiella, Shigella, and Proteus. DNA homologies among the different Erwinia species were in most cases below $50 \%$, even under nonstringent annealing conditions. In most instances DNA homologies between Erwinia species and Escherichia, Salmonella, Klebsiella, and Shigella species showed about the same amount of relatedness as in Erwinia-to-Erwinia combinations. The molecular hybridization data indicate that the genus Erwinia is a loosely composed group of bacteria that often have no greater affinities to each other than to other enteric bacteria. Furthermore, the data do not support some of the previously proposed taxonomic divisions within the genus Erwinia.
\end{abstract}

The genus Erwinia, established in 1917 in honor of the phytopathologist Erwin F. Smith by a nomenclature committee headed by Winslow et al. (25), was initially based heavily on plant pathogenicity with little emphasis on other phenotypic characters. Thereafter many new species were placed in this genus almost solely on the basis of host parasitism. Taxonomic subdivisions within the genus Erwinia are currently based on morphological, biochemical, and physiological tests, but the emphasis on plant parasitism has led to the creation of numerous "new" species. Martinec and Kocur (21) suggested that many Erwinia spp. be lumped into two groups, with E. amylovora and $E$. carotovora being the typical species of the groups. Dye (1st Int. Congr. Plant Pathol., London, July 1968, Abstr. 51) recommended consolidating the numerous Erwinia species into five species (E. amylovora, E. carotovora, $E$. herbicola, E. uredovorus, and E. stewartii). Ewing and Fife (11) placed E. herbicola, $E$. lathyri, and other erwinias of this kind into the genus Enterobacter under a single species, $E$. agglomerans. Physiological-biochemical tests are useful pragmatically but are not always successful in establishing systematic relationships. We believe that deoxyribonucleic acid (DNA) reassociation measurements are more accurate and realistic from a strictly taxonomic point of view. The suggestion has been made previously that the genus Erwinia be dissolved and the members distributed among the enterobacteria (23). On the basis of heterogeneous DNA base compositions, Starr and Mandel (24) suggested that one can only be agnostic about the status of the genus. We have, therefore, attempted to study the validity of the genus Erwinia, its relationship to the other genera in the family Enterobacteriaceae, and the proposed subdivision of the genus on the basis of DNA sequence homologies. Brenner et al. (5) recently reported DNA-homology data for 5 strains of Erwinia and 11 strains of other organisms belonging to the family Enterobacteriaceae. Their data indicate a low but significant homology between the erwinias and between the erwinias and other members of the family Enterobacteriaceae. Our data, obtained by a hybridization technique different from that used by Brenner et al., confirm this same trend with a wider range of species and strains.

\section{MATERIALS AND METHODS}

Bacterial cultures. The source of cultures is listed in Table 1. Bacteria were grown with shaking in medium 523 broth (14) and harvested by centrifugation during the late $\log$ phase, washed in BE buffer $(0.05 \mathrm{M}$ 
sodium borate, $\mathrm{Na}_{2}$ ethylenediaminetetraacetic acid, $p \mathrm{H} 9.0)$, and stored in a frozen state $(-20 \mathrm{C})$.

Labeling of DNA. For ${ }^{32} \mathrm{PO}_{4}$-labeled DNA, cells were grown in low-phosphate medium (12). Carrierfree ${ }^{32} \mathrm{PO}_{4}$-phosphoric acid (Schwartz-Mann, Orangeburg, N.J.) was added to the medium $(1 \mu \mathrm{Ci} / \mathrm{ml}$ of medium) and the cells were then harvested in the late $\log$ phase. The same procedure applied for ${ }^{14} \mathrm{C}$-DNA except that cells were grown in medium 925 salts (17) plus $0.7 \%$ glucose, $1 \mathrm{~mm}$ deoxyguanosine, nicotinic acid, $(50 \mu \mathrm{g} / \mathrm{ml})$, and $0.05 \%$ Casamino Acids. ${ }^{14} \mathrm{C}$-uridine $(50 \mathrm{mCi} / \mathrm{mmole})$ plus ${ }^{1} \mathrm{C}$-adenine $(52$ $\mathrm{mCi} / \mathrm{mmole}$ ) (Schwartz-Mann) were added to give a final concentration of $0.5 \mu \mathrm{Ci} / \mathrm{ml}$ of medium. Specific activities were from 10,000 to 15,000 counts per min per $\mu \mathrm{g}$ for ${ }^{32} \mathrm{PO}_{4}$-labeled DNA and 6,500 counts per min per $\mu \mathrm{g}$ for ${ }^{14} \mathrm{C}$-labeled DNA.

DNA preparation. DNA was prepared by a modification of Marmur's technique (19). Erwinia spp. were lysed by a combination of freeze-thawing, lysozyme, and sodium dodecyl sulfate treatments, in that order. The lysed cells were extracted twice with phenol and twice with chloroform-octanol $(24: 1, v / v)$, and the DNA was then precipitated with 0.6 vol of freezing isopropanol. Treatments with pancreatic ribonuclease (preheated at $80 \mathrm{C}$ for $10 \mathrm{~min} ; 50 \mu \mathrm{g} / \mathrm{ml}, 37 \mathrm{C}, 2 \mathrm{hr}$ ) and Pronase (predigested for $2 \mathrm{hr}$ at $37 \mathrm{C} ; 1 \mathrm{mg} / \mathrm{ml} ; 37$ $\mathrm{C}, 6$ to $12 \mathrm{hr}$ ) were followed by additional chloroform-octanol extractions and repeated precipitations with chilled isopropanol. In a few cases where persistent polysaccharide contamination was a problem, Kirby's methoxyethanol extraction procedure (15) was followed. The final preparation of DNA was dissolved in $0.1 \times \mathrm{SSC}(1 \times \mathrm{SSC}=0.15 \mathrm{M} \mathrm{NaCl}, 0.015$ M sodium citrate, $p H$ 7.0). The purity of each DNA preparation was checked by determination of absorbancy ratios, $260 / 280 \mathrm{~nm}(1.85$ to 1.90$)$ and $260 / 230$ nm (2.2 to 2.3$)$, by sharp melting $\left(T_{\mathrm{m}}\right)$ curves which included hyperchromicity values of 35 to $40 \%$, and in some cases by appropriate $T_{\mathrm{m}}$ values.

For purifying sheared labeled DNA, the methods of Berns and Thomas (1) as modified by Brenner and Cowie (2) were used. DNA was sheared by repeated passage of the solution through syringes with 27 and 32 gauge needles. For competitive hybridization, competitor DNA $(1 \mathrm{mg} / \mathrm{ml})$ was sheared at $20,000 \mathrm{psi}$ in a French pressure cell. Sheared DNA fragments in $0.1 \mathrm{M}$ sodium phosphate buffer $(p H$ 6.8) were collected on hydroxyapatite, eluted with $0.5 \mathrm{M}$ of the same buffer, and dialyzed extensively against $0.1 \times$ SSC. The ${ }^{32}$ P-DNA solutions were passed through metrical filter discs (Gelman Instrument $\mathrm{Co}$., Ann Arbor, Mich.) to remove any possible ${ }^{32} \mathrm{PO}_{4}$ (as poly phosphates) contamination.

Melting profiles and calculation of percent GC. The procedures of Marmur and Doty (20) were used to calculate the mole percent guanine plus cytosine (GC) in the DNA from $T_{m}$ values. DNA was diluted in $0.1 \times \mathrm{SSC}$ to approximately $50 \mu \mathrm{g} / \mathrm{ml}$, and a deoxyadenosine or deoxyguanosine solution in $0.1 \times \mathrm{SSC}$ of equal absorbancy at $260 \mathrm{~nm}$ was used for a reference. The sample was melted in a Beckman Acta III dual-beam recording spectrophotometer equipped with matching thermal cuvette holders with inductive

TABLE 1. Culture sources

\begin{tabular}{cc}
\hline Organism & Source \\
\hline
\end{tabular}

Erwinia amylovora FB1

E. amylovora ICPB

EA $167^{\mathrm{a}}$

E. amylovora $\mathrm{ICPB}$

EA 178

E. carotovora $3 \mathrm{D} 31$

E. carotovora EC201

E. carotovora 3D 36

E. nigrifluens $130-\mathrm{C}$

E. nigrifluens $131-\mathrm{B}$

E. nigrifluens ICPB

EN104

E. nigrifluens 5D 313

E. rubrifaciens 6D 34

E. rubrifaciens 6D 321

E. rubrifaciens 6D 325

E. rubrifaciens $6 \mathrm{D} 326$

E. rubrifaciens 6D 327

E. rhapontici 8D31

E. aroideae ICPB EA14

E. nimipressuralis $12 \mathrm{D} 3$

$E$. dissolvens 14D3

E. uredovora $\mathrm{ICPB}$

XU 102

E. herbicola ICPB 3161

E. herbicola Y46

E. herbicola 25D35

E. herbicola 25D36

E. herbicola ICPB 2950

E. herbicola ICPB 2858A

Escherichia coli AB 295

E. coli Q13

Klebsiella aerogenes 19D3 $K$. pneumoniae M5A1

Salmonella typhimurium LT-2

Shigella dysenteriae

NCPB 32

\section{S. flexneri NCPB 27}

Proteus mirabilis 27D3

Agrobacterium tume-

faciens 1D135

Pseudomonas viridiflava PV -4

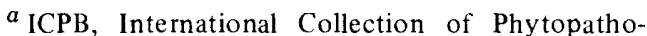
genic Bacteria (ICPB), Department of Bacteriology, University of California (UC), Davis.
M. Schroth, UC, Berkeley

M.P. Starr, UC, Davis

M. P. Starr, UC, Davis

R. H. Segall, USDA, Orlando, Fla.

M. Schroth, UC, Berkeley

C. I. Kado, UC, Davis

E. E. Wilson, UC, Davis

E. E. Wilson, UC, Davis

M. P. Starr, UC, Davis

J. M. Gardner, UC, Davis

E. E. Wilson, UC, Davis

E. E. Wilson, UC, Davis

J. M. Gardner, UC, Davis

J. M. Gardner, UC, Davis

J. M. Gardner, UC, Davis

M. P. Starr, UC, Davis

E. E. Wilson, UC, Davis

E. E. Wilson, UC, Davis

M. P.Starr, UC, Davis

M. P. Starr, UC, Davis

A. K. Chatterjee, UC, Davis

J. M. Gardner, UC, Davis

C. I. Kado, UC, Davis

M. P. Starr, UC, Davis

M. P. Starr, UC, Davis

A. J. Clark, UC, Berkeley

A. J. Wahba, U. Sherbrooke Quebec

D. G. Gilchrist, UC, Davis

R. C. Valentine, UC, Berkeley

J. L. Ingraham, UC, Davis

National Center for

Primate

Research,

U. C. Davis

National Center for

Primate

Research,

U. C. Davis

E. L. Biberstein, UC, Davis

C. I. Kado, UC, Davis

P. C. Pecknold, UC, Davis
E. E. Wilson, UC, Davis 
stirrers and with a linear temperature programmer connected to an accurately calibrated platinum thermocouple probe $( \pm 0.001 \mathrm{C})$ positioned directly in the DNA solution during melting. (The programmer, matching cuvettes, and thermocouple were redesigned for improved accuracy through the cooperation of Beckman Instruments, Fullerton, Calif.). The temperature was increased at a rate of $0.5 \mathrm{C}$ per min through the range of DNA melting. Melting curves were recorded on a Honeywell $x-y$ recorder.

Determination of homology. Denatured DNA $(600$ $\mu \mathrm{g}$ in $100 \mathrm{ml}$ of $5 \times \mathrm{SSC}$ ) was immobilized on $47-\mathrm{mm}$ diameter nitrocellulose filters (Schleicher and Schuell, B-6; reference 13). The amount of DNA retained on $6-\mathrm{mm}$ filter discs (cut from $47-\mathrm{mm}$ filters) was checked by diphenylamine (6) and found to be approximately $15 \mu \mathrm{g} / \mathrm{disc}$ in all cases. Filters were placed in glass vials $(15$ by $45 \mathrm{~mm})$ and pretreated with the preincubation mixture of Denhardt (8) for about $6 \mathrm{hr}$. The liquid was removed with a vacuum pipette. DNA duplex formation in formamide-SSC was done by the method described by McConaughy et al. (22). A $0.1-\mathrm{ml}$ amount of $20 \times \mathrm{SSC}, 0.2 \mathrm{ml}$ of $99 \%$ formamide (Mallinckrodt reagent), and $0.1 \mathrm{ml}$ of 0.5 to $1.0 \mu \mathrm{g}$ of sheared, heat-denatured, labeled DNA were added to the vials (i.e., 15:1 filter DNA to radioactive DNA). Sheared, labeled DNA was heatdenatured by heating at $100 \mathrm{C}$ for $10 \mathrm{~min}$ and immersing in an ice bath. The vials were shaken in a temperature-controlled water bath for approximately $48 \mathrm{hr}$. Hybridization was performed at temperatures ranging from 30 to $48 \mathrm{C}$ (about $18 \mathrm{C}$ to $36 \mathrm{C}$ below $T_{\mathrm{m}}$ of labeled DNA), depending on the experiment. Each sample was run in triplicate. The filters were washed twice with $0.5 \mathrm{ml}$ of $48 \%$ formamide- $5 \times \mathrm{SSC}$ and once in $4 \mathrm{ml}$ of $3 \times \mathrm{SSC}$ at the hybridization temperature, transferred to scintillation vials, dried, and counted in a nonaqueous scintillation fluid ( $4 \mathrm{~g}$ of diphenyloxazole and $0.1 \mathrm{~g}$ of 1,4-bis(2-[5-phenyloxazolyl])-benzene/ 1 toluene). From 40 to $50 \%$ of the homologous radioactive DNA was bound by filter DNA. The optimal time for maximum reassociation was about $50 \mathrm{hr}$ (Fig. 1, inset). Filters lost no detectable DNA during this period as tested by the diphenylamine reaction. In competition experiments a mixture containing $0.1 \mathrm{ml}$ of $30 \times \mathrm{SSC}, 0.3 \mathrm{ml}$ of $98 \%$ formamide, $0.15 \mathrm{ml}$ of sheared, heat-denatured, competitor DNA (total $150 \mu \mathrm{g}$ ), and $0.05 \mathrm{ml}$ of radioactive DNA $(1 \mu \mathrm{g})$ was incubated with the filters. Percent competition was calculated as follows:

$\%$ competition $=[\mathrm{cpm}$ bound (homologous) $-\mathrm{cpm}$ bound in presence of heterologous DNA]/[cpm bound (homologous) - cpm bound in presence of homologous DNA] x 100.

It was shown by a competition curve that $150 \mu \mathrm{g}$ of homologous DNA competitor was near the saturation level of this system (Fig. 1).

Melting of filter hybrids. Washed radioactive filters in $1.0 \mathrm{ml}$ of $0.1 \times \mathrm{SSC}$ or $5 \times \mathrm{SSC}-48 \%$ formamide were heated at various temperatures in an equilibrated linear thermal gradient bar (14) for $30 \mathrm{~min}$. Duplicate tubes containing the filters were then rapidly cooled in ice, and the filters were washed, dried, and counted as above.

\section{RESULTS}

Percent GC. The mole percent GC values of the DNA (Table 2) indicate that a fairly wide range of values (from 51 to $57 \%$ ) exists within the genus Erwinia and that a similar range exists among the other organisms of the family Enterobacteriaceae tested. From these data alone, the erwinias cannot be distinguished from other members of the family. Furthermore, no correlation was observed when the differences in percent GC and DNA relatedness to test species were plotted.

DNA homologies. Radioactive DNA from four Erwinia species (E. amylovora, E. herbicola, E. carotovora, and E. rubrifaciens) was hybridized to filter-bound DNA from other erwinias as well as from other organisms in the

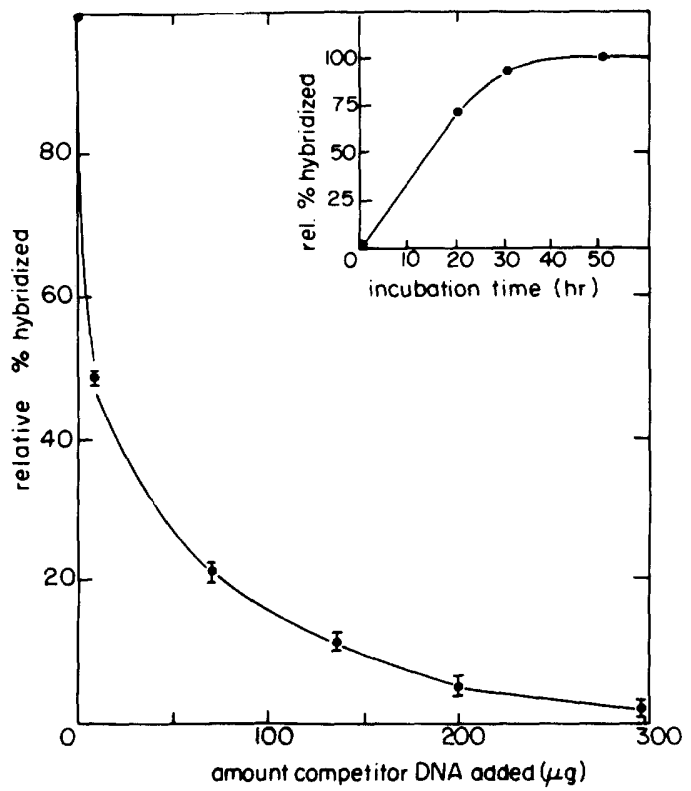

FIG. 1. Competition between Erwinia rubrifaciens $6 D 321 D N A$ and $6 D 321{ }^{14} C-D N A$ for hybridization to homologous filter DNA. Hybridization without competitor was set at $100 \%$. Hybridization with or without competitor DNA was done at $45 \mathrm{C}$ in $0.6 \mathrm{ml}$ of $5 \times S S C$ in $48 \%$ formamide. Inset: Time course for direct hybridization of $6 D 321{ }^{14} \mathrm{C}-D N A$ to homologous filter DNA. Hybridization was done at $41 \mathrm{C}$ in $0.4 \mathrm{ml} 5 \times \mathrm{SSC}$ in $48 \%$ formamide. Hybridization at $50 \mathrm{hr}$ was set at $100 \%$. Hybridization was extended to $160 \mathrm{hr}$ to insure that a single plateau was reached by $50 \mathrm{hr}$. 
TABLE 2. Percent GC values for DNA preparations and DNA homologies between Erwinia rubrifaciens and other members of the family Enterobacteriaceae

\begin{tabular}{|c|c|c|c|c|c|c|c|}
\hline \multirow[b]{3}{*}{ Source of unlabeled DNA } & \multirow{3}{*}{$\begin{array}{c}\text { Percent } \\
\mathrm{GC}^{b}\end{array}$} & \multicolumn{6}{|c|}{ Relative binding (\%) ${ }^{a}$} \\
\hline & & \multicolumn{4}{|c|}{$\begin{array}{c}\text { Direct } \\
\text { hybridization at }(\mathrm{C})\end{array}$} & \multicolumn{2}{|c|}{$\begin{array}{c}\text { Competitive } \\
\text { hybridization } \\
\text { at (C) }\end{array}$} \\
\hline & & 30 & 37 & 41 & 45 & 36 & 45 \\
\hline Erwinia rubrifaciens ER 103. & $51.7(51.5) c$ & 100 & 100 & 100 & 100 & 100 & 100 \\
\hline E. rubrifaciens $6 \mathrm{D} 327 \ldots \ldots \ldots \ldots$ & 51.7 & & 103 & & 100 & & 100 \\
\hline E. rubrifaciens $6 \mathrm{D} 325 \ldots \ldots \ldots \ldots$ & 51.3 & 104 & & & 100 & & \\
\hline E. rubrifaciens $6 \mathrm{D} 326 \ldots \ldots \ldots \ldots$ & 52.4 & 100 & & 91 & 99 & & 103 \\
\hline E. rubrifaciens $6 \mathrm{D} 34 \ldots \ldots \ldots \ldots$ & 52.1 & 95 & & 91 & 92 & 98 & 95 \\
\hline E. nigrifluens EN104 .......... & 56.3 & 37 & & 35 & 37 & 53 & 34 \\
\hline E. nigrifluens $130-C \ldots \ldots \ldots \ldots$ & 56.7 & 44 & & 27 & 32 & & \\
\hline E. nigrifluens $131-\mathrm{B} \ldots \ldots \ldots \ldots$ & & 48 & & 36 & 41 & 67 & \\
\hline 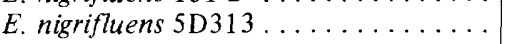 & 56.3 & & 42 & & 37 & & 33 \\
\hline E. amylovora EA167 .......... & 54.1 & 36 & 24 & 17 & 15 & & \\
\hline E. amylovora $\mathrm{FB1} \ldots \ldots \ldots \ldots$ & 54.9 & 27 & & 14 & 9 & & \\
\hline E. amylovora EA $178 \ldots \ldots \ldots$ & & 36 & 23 & & 13 & & 12 \\
\hline E. carotovora $3 \mathrm{D} 31 \ldots \ldots \ldots$ & 52.1 & 36 & & 26 & & & 17 \\
\hline E. carotovora $\mathrm{EC} 201 \ldots \ldots \ldots$ & 53.9 & 33 & & 24 & 17 & 45 & \\
\hline E. carotovora 3D $36 \ldots \ldots \ldots \ldots$ & & 39 & & & 23 & & 17 \\
\hline E. herbicola ICPB $3161 \ldots \ldots \ldots$ & 54.3 & 32 & & 13 & 10 & & 10 \\
\hline E. herbicola Y $46 \ldots \ldots \ldots \ldots \ldots$ & 54.8 & 32 & & 15 & 13 & & \\
\hline E. herbicola 25D35 . . . . . . . . & 53.3 & & 34 & & 19 & & \\
\hline E. herbicola $25 \mathrm{D} 36 \ldots \ldots \ldots \ldots \ldots$ & 55.2 & 35 & & 19 & 17 & & \\
\hline E. herbicola $2950 \ldots \ldots \ldots \ldots \ldots \ldots$ & & & & & 19 & & 9 \\
\hline E. herbicola $2858 \mathrm{~A} \ldots \ldots \ldots \ldots \ldots$ & & & & & 15 & & \\
\hline 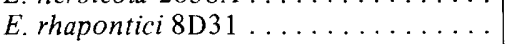 & 53.2 & & 28 & & 19 & & \\
\hline 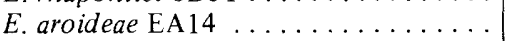 & 53.2 & 27 & & 14 & 9 & & 19 \\
\hline E. nimipressuralis $12 \mathrm{D} 3$ & 55.3 & 29 & & 18 & 15 & & 12 \\
\hline E. dissolvens 14D3 .... & 53.5 & & & & 19 & & 15 \\
\hline E. uredovora XU102 ... & 53.5 & & 29 & & 16 & & 10 \\
\hline Escherichia coli $\mathrm{AB} 295 \ldots \ldots \ldots \ldots$ & 51.9 & 38 & & & 16 & & \\
\hline E. coli $\mathrm{Q} 13 \ldots \ldots \ldots \ldots$ & & 40 & & & 22 & & \\
\hline Klebsiella aerogenes 19D3 & 58.2 & & 31 & 15 & 20 & & 14 \\
\hline K. pneumoniae M5A $1 \ldots \ldots \ldots \ldots$ & 58.2 & 37 & & & 19 & & \\
\hline Salmonella typhimurium LT-2 . . . . . & 51.9 & 26 & & 19 & 20 & & 10 \\
\hline Proteus mirabilis 27D3 . . . . . & 42.2 & & & & 2 & & 2 \\
\hline Shigella flexneri $27 \ldots$ & & & & & 6 & & 10 \\
\hline Shigella dysenteriae $32 \ldots \ldots \ldots \ldots$ & & & & & 6 & & 10 \\
\hline Agrobacterium tumefaciens ${ }^{d}$ 1D135 .. & $60.5^{e}$ & 13 & & & 0 & & 1 \\
\hline Pseudomonas viridiflavad PV 4 . . . . . & & & & & 0 & & \\
\hline Calf thymus ${ }^{d} \ldots \ldots \ldots \ldots \ldots$ & & & & & 0 & & \\
\hline
\end{tabular}

${ }^{a}$ For direct hybridization, $1.0 \mu \mathrm{g}$ of ${ }^{14} \mathrm{C}$-labeled DNA in a total volume of $0.4 \mathrm{ml}$ of $5 \times \mathrm{SSC}-48 \%$ formamide was incubated with $15 \mu \mathrm{g}$ of unlabeled DNA fixed on $6-\mathrm{mm}$ filters for $48 \mathrm{hr}$. For competitive hybridization, the reaction volume was increased to $0.6 \mathrm{ml}$, and $150 \mu \mathrm{g}$ of sheared-unlabeled DNA was added to the reaction mixture.

$b$ Percent GC determined by optical thermal denaturation (20). Each value represents an average based on usually three or more determinations. GC variations from the mean were less than $0.6 \%$.

${ }^{c}$ Percent GC determined by melting radioactive filter hybrid (average of two determinations).

$d$ Not a member of the family Enterobacteriaceae.

${ }^{e}$ From reference (14).

family. The hybridization data show that the degree of relative homologies was under $40 \%$ in most cases and clustered in this range (Tables 2-5). Incubation temperatures ranged from the stringent reannealing temperature of $48 \mathrm{C}$ (ca. $18 \mathrm{C}$ below $T_{\mathrm{m}}$ ) to the nonstringent reannealing temperature of $30 \mathrm{C}$ (ca. $36 \mathrm{C}$ below $T_{\mathrm{m}}$ ). Above $37 \mathrm{C}$ (ca. $29 \mathrm{C}$ below $T_{\mathrm{m}}$ ) there was no significant hybridization with DNA from Agrobacterium tumefaciens or Pseudomonas 
viridiflava, which are not members of the family Enterobacteriaceae, or with calf thymus, indicating that hybridization conditions were specific. At the nonstringent temperature of 30 C, 8 to $13 \%$ homology was obtained with $A$. tumefaciens. Even at this temperature $(36 \mathrm{C}$ below $T_{\mathrm{m}}$ ) most homologies among all other bacteria remained below $50 \%$. Results of competitive hybridization experiments agreed with those of direct hybridization, and percent homologies, with one exception, fell in the same range as those of direct hybridization ( 10 to $50 \%$ ). The only comparatively high hybridization values (ca. $40 \%$ ) were between $E$. rubrifaciens and $E$. nigrifluens under stringent reannealing conditions $\left(21 \mathrm{C}\right.$ below $\left.T_{\mathrm{m}}\right)$. Competitive hybridization gave values as high as $67 \%$ for this combination at relatively nonstringent temperatures ( $36 \mathrm{C}$ below $T_{m}$ ). Comparative DNA homologies of other erwinias and members of the family with $E$. herbicola, $E$. amylovora, E. carotovora, and E. rubrifaciens were clearly so low and tightly clustered that no meaningful differences were possible to define. Proteus mirabilis was the only exception within the family, since no homology was detected with $E$. rubrifaciens. This would be expected based on a $10 \%$ difference in GC.
Mispairing in the DNA hybrids was estimated by melting the filter-bound radioactive hybrids. Homologous hybrids produced sharp helix-tocoil transitions with $T_{\mathrm{m}}$ values similar to those obtained by the optical melting technique. On the other hand, heterologous hybrids melted over a relatively broad temperature range (Fig. 2 and 3). The thermal instability of the heterologous hybrids on filters indicates that even under moderately stringent hybridization conditions (22 C below $T_{\mathrm{m}}$ ) mispaired bases were present in the hybrids. According to Laird et al. (16), a $1 \%$ alteration in base pairing will decrease the $T_{\mathrm{m}}$ by $0.7 \mathrm{C}$, although this value can vary by a factor of 2 (5). By this estimate (Fig. 2 and 3), about $8 \%$ and $14 \%$ base mispairing is present in the $E$. nigrifluens- $E$. rubrifaciens and $E$. herbicola-E. rubrifaciens DNA hybrids, respectively.

\section{DISCUSSION}

Our studies show that no distinct relationships are evident between the Erwinia species and between erwinias and other members of the family Enterobacteriaceae based on GC values

TABLE 3. DNA homologies between Erwinia herbicola and other members of the family Enterobacteriaceae

\begin{tabular}{|c|c|c|c|c|c|}
\hline \multirow[b]{3}{*}{ Source of unlabeled DNA } & \multicolumn{5}{|c|}{ Relative binding $(\%)^{a}$} \\
\hline & \multicolumn{3}{|c|}{$\begin{array}{c}\text { Direct } \\
\text { hydridization at }(\mathrm{C})\end{array}$} & \multicolumn{2}{|c|}{$\begin{array}{c}\text { Competitive } \\
\text { hybridization at }(\mathrm{C})\end{array}$} \\
\hline & 39 & 40 & 48 & 39 & 46 \\
\hline Erwinia herbicola ICPB $3161 \ldots \ldots \ldots$ & 100 & 100 & 100 & 100 & 100 \\
\hline E. herbicola $25 \mathrm{D} 31 \ldots \ldots \ldots \ldots \ldots \ldots$ & 96 & 101 & 96 & 96 & \\
\hline$\ldots \ldots \ldots \ldots \ldots$ & 120 & 110 & 114 & 99 & \\
\hline$\ldots \ldots \ldots \ldots \ldots \ldots$ & 25 & 24 & 7 & 19 & \\
\hline E. rubrifaciens $6 \Gamma^{\wedge} 21$ & 16 & 16 & & 15 & 5 \\
\hline E. rubrifaciens $6 \mathrm{D} 326$ & 19 & 11 & 7 & & \\
\hline E. amylovora FB1 ... & 24 & 12 & 6 & & 6 \\
\hline E. amylovora EA 167 & 36 & 35 & 16 & & 13 \\
\hline E. carotovora $3 \mathrm{D} 31 \ldots \ldots \ldots \ldots$ & & 16 & 5 & & \\
\hline E. carotovora $\mathrm{EC} 201 \ldots \ldots \ldots \ldots \ldots$ & 31 & 29 & 19 & & 17 \\
\hline E. nigrifluens $130-\mathrm{C} \ldots \ldots \ldots \ldots \ldots \ldots$ & & 14 & & & 5 \\
\hline E. nigrifluens $131-\mathrm{B} \ldots \ldots \ldots \ldots \ldots \ldots \ldots \ldots \ldots \ldots \ldots$ & 16 & 16 & 12 & 16 & 21 \\
\hline E. nigrifluens F N104 . . & 26 & 29 & 6 & & 16 \\
\hline E. nimipressuralis $12 \mathrm{D} 3 \ldots \ldots$ & 29 & 35 & 17 & 16 & \\
\hline E. dissolvens $14 \mathrm{D} 3 \ldots \ldots \ldots$ & 33 & 35 & 8 & 15 & 21 \\
\hline Escherichia coli AB295 ... & 36 & & 11 & 14 & 14 \\
\hline Salmonella typhimurium LT-2 . . & 39 & 29 & 11 & & \\
\hline Klebsiella aerogenes 19D $3 \ldots \ldots \ldots$ & 29 & 28 & 10 & 29 & \\
\hline Agrobacterium tumefaciens ${ }^{b} 1 \mathrm{D} 135 \ldots$ & 2 & & 0 & 0 & \\
\hline Calf thymus ${ }^{b} \ldots \ldots \ldots \ldots \ldots \ldots \ldots$ & & 0 & & & \\
\hline
\end{tabular}

${ }^{a}$ Methods were as described in Table 2 except that ${ }^{32} \mathrm{PO}_{4}$-DNA was used.

$b$ Not a member of the family Enterobacteriaceae. 
TABLE 4. DNA homologies between Erwinia amylovora and other members of the family Enterobactericeae

\begin{tabular}{|c|c|c|c|c|c|}
\hline \multirow[b]{3}{*}{ Source of unlabeled DNA } & \multicolumn{5}{|c|}{ Relative binding (\%) ${ }^{a}$} \\
\hline & \multicolumn{3}{|c|}{$\begin{array}{c}\text { Direct } \\
\text { hybridization at }(\mathrm{C})\end{array}$} & \multicolumn{2}{|c|}{$\begin{array}{c}\text { Competitive } \\
\text { hybridization at }(\mathrm{C})\end{array}$} \\
\hline & 30 & 39 & 44 & 35 & 46 \\
\hline 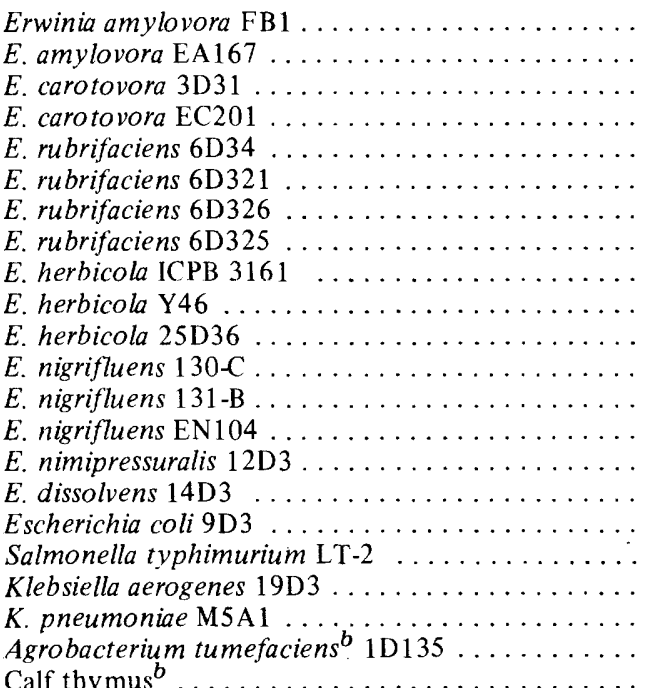 & $\begin{array}{l}49 \\
35 \\
\\
30 \\
40 \\
37 \\
45 \\
45 \\
28\end{array}$ & $\begin{array}{l}35 \\
32 \\
17 \\
27 \\
19 \\
23 \\
18 \\
22 \\
26 \\
18\end{array}$ & $\begin{array}{r}100 \\
101 \\
13 \\
8 \\
14 \\
15 \\
13 \\
\\
27 \\
22 \\
32 \\
\\
13 \\
15 \\
19 \\
12 \\
19 \\
19 \\
\end{array}$ & $\begin{array}{l}34 \\
36 \\
43 \\
34 \\
34 \\
41 \\
36 \\
32 \\
23\end{array}$ & $\begin{array}{l}22 \\
18 \\
10 \\
10 \\
15 \\
14 \\
18\end{array}$ \\
\hline
\end{tabular}

${ }^{a}$ Methods were as described in Table 2 except that ${ }^{32} \mathrm{PO}_{4}$-DNA was used.

$b$ Not a member of the family Enterobacteriaceae.

in combination with DNA-homology data. Attempts to group the erwinias into a few species by using GC contents alone is obviously misleading. For example, the $\mathrm{GC}$ values of $51 \%$ for $E$. rubrifaciens and $56 \%$ for $E$. nigrifluens are distant, and yet the DNA homology is closer between these two organisms than any other combination and was the highest encountered (32 to $41 \%$ ). Starr and Mandel (24) noted that percent GC clusters among certain erwinias, notably the soft-rot- $E$. carotovora group, correlate well with groupings based on physiological data. However, they admit that such a correlation may be purely fortuitous. Instead, the range of $\mathrm{GC}$ values may indicate significant disparity among the erwinias and other organisms in the family. Irrespective of the GC data, our DNA reassociation experiments show very little homology between Erwinia species and the other organisms of the family tested. Even if some small differences in homologies were shown to be statistically different (e.g., 1 to $10 \%$ differences), the taxonomic significance of such small differ-
TABLE 5.DNA homologies between Erwinia carotovora $3 D 32$ and other members of the family Enterobacteriaceae

\begin{tabular}{|c|c|}
\hline Source of unlabeled DNA & $\begin{array}{c}\text { Relative } \\
\text { binding } \\
\text { at } 35 \mathrm{C}(\%)^{a}\end{array}$ \\
\hline Erwinia carotovora EC201 & 100 \\
\hline E. amylovora $\mathrm{FB} 1$ & 12 \\
\hline E. amylovora EA 167 & 24 \\
\hline E. herbicola ICPB 3161 & 14 \\
\hline E. herbicola Y46 & 29 \\
\hline E. rubrifaciens $6 \mathrm{D} 321$ & 25 \\
\hline E. rubricaciens $6 \mathrm{D} 326$ & 27 \\
\hline E. nigrifluens $131-\mathrm{B}$ & 45 \\
\hline E. nigrifluens EN104 & 34 \\
\hline E. nimipressuralis $12 \mathrm{D} 3$ & 27 \\
\hline E. dissolvens $14 \mathrm{D} 3$ & 25 \\
\hline Escherichia coli $\mathrm{AB} 295$ & 26 \\
\hline Klebsiella aerogenes 19D3 & 36 \\
\hline Salmonella typhimurium LT-2 & 33 \\
\hline Agrobacterium tumefaciens ${ }^{b}$ 1D135 & 5 \\
\hline
\end{tabular}

${ }^{a}$ Direct hybridization done as described in Table 2 except that ${ }^{32} \mathrm{PO}_{4}-$ DNA was used.

${ }^{b}$ Not a member of the family Enterobacteriaceae. 


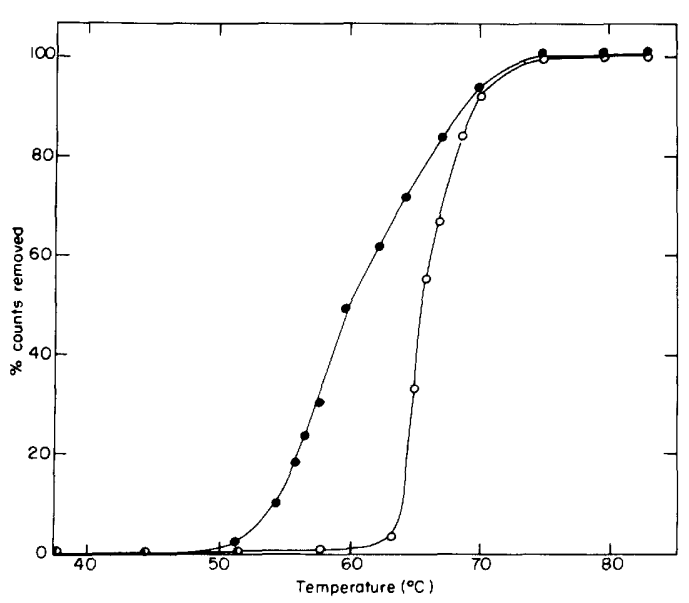

FIG. 2. Thermal denaturation of homologous and heterologous DNA duplexes by Erwinia rubrifaciens 6D321 DNA:6D321 DNA (O) E. rubrifaciens 6D321:E. nigrifluens 5D313 DNA (O). Melting was done in $5 \times S S C-48 \%$ formamide. Sheared, denatured $6 D 321^{14} \mathrm{C}-D N A(0.8 \mu \mathrm{g})$ in a total volume of $0.4 \mathrm{ml}$ of $5 \times S S C-48 \%$ formamide was reacted with homologous 6D321 DNA and heterologous 5D313 DNA filters at $45 \mathrm{C}$. Filters were then washed and incubated in $1.0 \mathrm{ml}$ of $5 \times S S C .48 \%$ formamide at various temperatures for $30 \mathrm{~min}$.

ences would be doubtful. More intensive reassociation techniques are necessary to study the family Enterobacteriaceae. For example, dissecting and enriching the genomes into related and unrelated sequences (e.g., using multiple competitors) may amplify genetic differences. Nevertheless, the erwinias appear to have certain genetic relatedness to other members of the family. Chatterjee and Starr (7) recently showed that drug-resistance factors and sex factors can be passed from Shigella dysenteriae and Escherichia coli, respectively, to erwinias. Our hybridization data suggest that regions of the Erwinia genome lend to such interchanges because of the small but significant sequence homologies. Kado et al. (in press) demonstrated that polyacrylamide-gel electropherograms of $70 S$ ribosomal proteins from $E$. rubrifaciens, E. nigrifluens, E. carotovora, and $E$. amylovora are strikingly similar to those of E. coli and Salmonella typhimurium, whereas A. tumefaciens ribosomal protein patterns are quite different. These similarities in ribosomal structural proteins also imply a significant degree of relatedness and conservation of ribosomal genes. Our data suggest that a small but significant common core of relatedness is present throughout the genomes of the mem- bers of the family Enterobacteriaceae including the Erwinia spp. tested here.

Many artificial groupings of Erwinia spp. were devised almost purely from phenotypic differences (e.g., pigment production, pathogenicity, sugar utilization, etc.). Some previous proposals to lump species of Erwinia are not supported by our data. For example, the proposal by Dye (9) that E. rubrifaciens and $E$. nigrifluens be considered as subspecies of $E$. amylovora is clearly artificial because of the low (13 to $15 \%$ ) DNA homologies with $E$. amylovora obtained in our experiments under stringent conditions. DNA-homology data of Brenner et al. (5) also demonstrate that the soft-rot organisms, E. aroideae (considered identical to $E$. carotovora by Dye [10]) and $E$. carnegieana, were only $46 \%$ and $5 \%$ related, respectively, to E. carotovora. Ewing and Fife (11) proposed that E. herbicola be transferred to Enterobacter as E. agglomerans on the basis of numerous physiological tests. This change in nomenclature is not supported by the $10 \%$ relative homology we found between $E$. herbicola and Klebsiella aerogenes (Enterobacter is a member of the tribe Klebsielleae), regardless of the fact that homologies between $E$. herbicola and other erwinias were not much higher. These authors also recommended that E. amylovora be removed from the family Enterobacteriaceae; our homology data indicate on the other hand that $E$. amylovora has 12 to $19 \%$ relative genetic homologies with other members of the

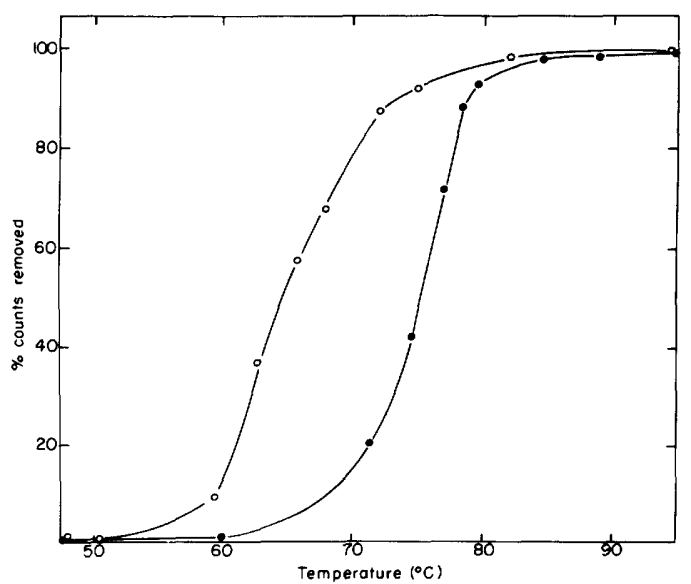

FIG. 3. Thermal denaturation of homologous and heterologous DNA duplexes by Erwinia rubrifaciens 6D321 DNA: E. rubrifaciens 6D321 DNA (O). E. rubrifaciens $6 D 321$ DNA:E. herbicola ICPB 3161 DNA (O). Conditions for hybrid formation and melting are the same as those described in Fig. 2. 
family under relatively stringent annealing conditions. From these data, it appears that the taxonomic proposals cited above and made on the basis of physiological tests have been misleading.

The heterogeniety of DNA-DNA and DNAribonucleic acid homologies among Shigella, Salmonella, Escherichia, and Proteus groups was evident from the studies of Brenner et al. (2-4). Most of the inter- and intragenus relationships were below $50 \%$ on the basis of DNA homology as confirmed here. Under stringent hybridization conditions, as much as $25 \%$ homology divergence was observed among strains of $E$. coli; a $23 \%$ divergence in genome size was also found among these strains. This suggests that much evolutionary (i.e., polynucleotide) divergence has taken place among organisms in the family Enterobacteriaceae. The present data showing a small but significant homology between all erwinias tested also suggest evolutionary divergence among Erwinia spp. E. rubrifaciens and E. nigrifluens are distinct and specific pathogens of Persian walnut and show the highest degree of DNA homology in our studies. This may suggest that parallel evolution is reflected by common polynucleotide sequences of these two organisms. Whether the small segments of homologous base sequences found between two given species are common to many or all of the erwinias or of the other organisms in the family must be tested by other DNA-reassociation techniques.

It is not clear at what point on the homology scale the lines for intraspecies and intragenus relatedness should be drawn. How far, for instance, can a genus or species diverge in evolution and still retain its nomenclature? Obviously, such rules must be made with both arbitrary and pragmatic considerations. Whether the genus Erwinia should be dissolved and its members reshuffled among the other genera of the family Enterobacteriaceae will be an academic as well as a pragmatic exercise. Although genetic homologies provide the most valid basis for classification, it may be that, in quoting Mandel (18), "Like good cigars, a good species and a good classification is one which satisfies."

\section{ACKNOWLEDGMENTS}

This investigation was supported by ARS grant 12-14-100-9930(34) from the IJ.S. Department of Agriculture and in part by Public Health Service grant CA-11526 from the National Cancer Institute and grant VC-49A from the American Cancer Society.
We thank Karl Drlica and Arun Chatterjee for helpful discussions and criticism and Mortimer Starr for ICPB cultures.

\section{LITERATURE CITED}

1. Berns, K. I., and C. A. Thomas. 1965. Isolation of high molecular weight DNA from Hemophilus influenzae. J. Mol. Biol. 11:476-490.

2. Brenner, D. J., and D. B. Cowie. 1968. Thermal stability of Escherichia coli-Salmonella typhimurium deoxyribonucleic acid duplexes. J. Bacteriol. 95:2258-2262.

3. Brenner, D. J., G. R. Fanning, K. E. Johnson, R. V. Citarella, and S. Falkow. 1969. Polynucleotide sequence relationships among members of Enterobacteriaceae. J. Bacteriol. 98:637-650.

4. Brenner, D. J., G. R. Fanning, F. J. Skerman, and S. Falkow. 1972. Polynucleotide sequence divergence among strains of Escherichia coli and closely related organisms. J. Bacteriol. 109:953-965.

5. Brenner, D. J., G. R. Fanning, and A. G. Steigerwalt. 1972. Deoxyribonucleic acid relatedness among species of Erwinia and between Erwinia species and other enterobacteria. J. Bacteriol. 110:12-17.

6. Burton, K. 1968. Determination of DNA concentration with diphenylamine, p. 163-166. In S. P. Colowick and N. O. Kaplan (ed.), Methods in enzymology, vol. 12. Academic Press Inc., New York.

7. Chatterjee, A. K., and M. P. Starr. 1972. Genetic transfer of episomic elements among Erwinia species and other enterobacteria: $\mathrm{F}^{\prime} \mathrm{lac}^{+}$. J. Bacteriol. 111:169-176.

8. Denhardt, D. T. 1966. A membrane filter technique for the detection of complementary DNA. Biochem. Biophys. Res. Commun. 23:641-646.

9. Dye, D. W. 1968. A taxonomic study of the genus Erwinia. I. The "amylovora" group. New Zealand J. Sci. 11:590-607.

10. Dye, D. W. 1968. A taxonomic study of the genus Erwinia. II. The "carotovora" group. New Zealand J. Sci. 12:81-97.

11. Ewing, W. H., and M. A. Fife. 1971. Enterobacter agglomerans. Part 1, The Herbicola-Lathyri bacteria. U.S. Dep. H. Ed. W. Pub. Health Rep. 4B5038871.

12. Friesen, J. D. 1968. Measurement of DNA synthesis in bacterial cells. Methods Enzymol. 128:625-635.

13. Gillespie, D., and S. Speigelman. 1965. A quantitative assay for DNA-RNA hybrids with DNA immobilized on a membrane. J. Mol. Biol. 12:829-842.

14. Kado, C. I., M. G. Heskett, and R. A. Langley. 1972. Studies on Agrobacterium tumefaciens: characterization of strains $1 \mathrm{D} 135$ and B6, and analysis of the bacterial chromosome, transfer RNA and ribosomes for tumor-inducing ability. Physiol. Plant Pathol. 2:47-57.

15. Kirby, K. S., E. Fox-Carter, and M. Guest. 1967. Isolation of deoxyribonucleic acid and ribonucleic acid from bacteria. Biochem. J. 104:258-262. 
16. Laird, C. D., B. L. McConaughy, and B. J. McCarthy. 1969. Rate of fixation of nucleotide substitution in evolution. Nature (London) 224:149-154.

17. Langley, R. A., and C. I. Kado, 1972. Studies on Agrobacterium tumefaciens: conditions for mutagenesis by methyl-N' -nitro-N-nitrosoguanidine and relationships of $A$. tumefaciens mutants to crown-gall tumor induction. Mutat. Res. 14:277-286.

18. Mandel, M. 1969. New approaches to bacterial taxonomy: perspectives and prospects. Annu. Rev. Microbiol. 23:239-274.

19. Marmur, J. 1961. A procedure for the isolation of deoxyribonucleic acid from microorganisms. J. Mol. Biol. 3:208-218.

20. Marmur, J., and P. Doty. 1962. Determination of the base composition of deoxyribonucleic acid from its thermal denaturation temperature. J. Mol. Biol. 5: 109-118.

21. Martinec, T., and M. Kocur. 1963. A taxonomic study of the genus Erwinia. Publ. Fac. Sci. Univ. J. E. Purkynye Bruno 4:1-160.

22. McConaughy, B., C. D. Laird, and B. J. McCarthy. 1969. Nucleic acid reassociation in formamide. Biochemistry 8:3289-3295.

23. Moustardier, G., J. Brisov, J. Saout, and J. P. Erhardt. 1961. Les Erwinia discussion taxonomique. Int. Med. Bull. Ass. Dipl. Microbiol. Nancy 82:2-12.

24. Starr, M. P., and M. Mandel. 1969. DNA base composition and taxonomy of phytopathogenic and other enterobacteria. J. Gen. Microbiol. 56:113-123.

25. Winslow, C. E. A., J. Broadhurst, R. E. Buchanan, C. Krumwiede, Jr., L. A. Rogers, and G. H. Smith 1917. The families and genera of the bacteria. Preliminary report of the Committee of the Society of American Bacteriologists on Characterization and classification of bacterial types. J. Bacteriol. 2:505-566. 